\title{
Biomass production of Azolla microphylla as biofilter in a recirculating aquaculture system
}

\author{
SUMOHARJO ${ }^{1, \vartheta}$, MOHAMMAD MA'RUF ${ }^{2, \vee v}$, IRWAN BUDIARTO ${ }^{3, \text { }}$, \\ ${ }^{1}$ Laboratory of Aquaculture System and Technology, Faculty of Fisheries and Marine Science, Universitas Mulawarman. Jl. Gunung Tabur, Kampus \\ Gunung Kelua, Samarinda 75116, East Kalimantan, Indonesia. Tel./fax.: +62-541-748648, `email: sumoharjo@ gmail.com

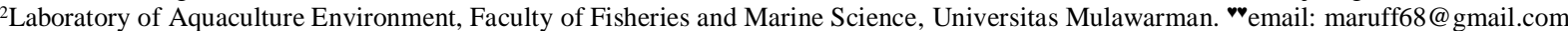

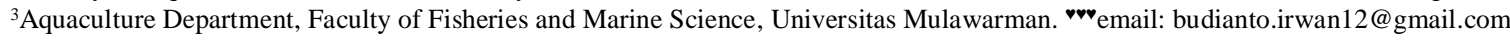

Manuscript received: 1 April 2018. Revision accepted: 20 May 2018.

\begin{abstract}
Sumoharjo, Ma'ruf M, Budiarto I. 2018.Biomass production of Azolla microphylla as biofilter in a recirculating aquaculture system. Asian J Agric 2: 14-19. This study utilized macrophyte (Azolla microphylla Kaulf.) as a biofilter and investigated that biomass produced in an aquaculture system could potentially be an alternative feed. This experiment was aimed to determine the Azolla microphylla growth rate and its efficiency in removing ammonia from a simple recirculating aquaculture system. The experimental units were set up in three different water flows, i.e. $3 \mathrm{lpm}, 5 \mathrm{lpm}$, and $7 \mathrm{lpm}$ onto the three different geometrically baseboards of Tilapia (Oreochromis niloticus) growing tanks (prism, rectangular and limas). The results showed that water flow did not give significant effect $(\mathrm{P}<0.10)$ on the growth rate of Azolla. The lower water flow $(3 \mathrm{lpm})$ resulted in the highest ammonia biofiltration efficiency, which can remove ammonia up to $32.2 \pm 3.0 \%$ of the total $\mathrm{NH}_{3}-\mathrm{N}$ and $\mathrm{NH}_{4}{ }^{+}-\mathrm{N}(\mathrm{TAN})$.
\end{abstract}

Keywords: Azolla microphylla, ammonia, biofiltration, recirculating, water flow

\section{INTRODUCTION}

The main problem in the intensification of aquaculture systems is water quality decreasing rapidly because of a high density of fish being reared with a high feed input in less water exchange. Hence, accumulation of fish metabolites, especially ammonia, tends to occur in waterbody and build-up to toxic level and affecting fish performance. Wastewater is accumulated, while feed is continuously added in a fish culture system (Rafee and Saad 2005).

In an intensive land-based fish farming system, the toxicity of excreted nitrogenous compounds is often a limiting factor (Bradfield 1985; Brune et al. 2003, Nerici et al. 2012). The toxicity of the total $\mathrm{NH}_{3}-\mathrm{N}$ and $\mathrm{NH}_{4}{ }^{+}-\mathrm{N}$ (TAN) increases with the $\mathrm{pH}$ of the water because TAN enters the organism as $\mathrm{NH}_{3}$ and the proportion of $\mathrm{NH}_{3}$ increases with higher $\mathrm{pH}$ (Randall and Tsui 2002; Nerici et al. 2012). When environmental TAN level increases, the excretion of ammonium by aquatic animals decrease and the ammonium levels in the blood and tissues rise (Nerici et al. 2012). Long-term exposure to ammonia increases glycemia, lipoxygenase and unsaturated Erythrocyte Fatty Acids (Liu and Sun Pan 2008). Chronic exposure to high TAN concentrations tends to damage the fish gills, which can contribute to decreased growth because of gas exchange efficiency (Handy and Poxton 1993; Nerici et al. 2012).

In Recirculating Aquaculture Systems (RAS), biofilter is the main component and known as low-cost water treatment to keep water quality suitable for fish growth and welfare. Biofilter technology was studied intensely, however, most of them are struggling on bacterial-based biofilters, such as nitrification by nitrifiers and nutrient assimilation by heterotrophs. Smith (2003) categorized biofilters into four main types, i.e., activated sludge, aquatic plant filters, fluidized bed filters, and fixed film.

Azolla microphylla is an aquatic fern. Many reports on Azolla have been published, but almost all of them are related to its function as a natural feed resource. Azolla was recommended by FAO (2009) as feed-in small-scale aquaculture and had been used as a main component in food for tilapia (Fiogbé et al. 2014). According to Lumpkin and Placknett (1980) and Van Hove (1989), Azolla under good conditions presents high productivity and protein content (generally $20-30 \%$, on a dw basis).

Growing Azolla seems easy (Datta 2011) because of its endosymbiotic blue algae, Anabaena azollae, that fixes nitrogen directly from the atmosphere (Van Howe 1989). So, Azolla is probably able to grow well in a relatively low nutrient environment. However, reports on Azolla as biofilter to remove nitrogen from the fish culture water are rare. Even though, as a macrophyte, Azolla should be served as a phototrophic converter at the trophic level. So, it has great potential as a biofilter for maintaining water quality in RAS as well as providing an alternative feed for growing-fishes.

This study focused on utilizing Azolla as biofilter in RAS. The experimental units were designed in integration of fish tank and Azolla growing bed to meet a series of recirculating systems. The experiment was divided into two parts; first was to analyze the effect of different water flow on Azolla growth rates, and the second one was to determine the optimum biomass of Azolla for converting nitrogen from fish waste. 


\section{MATERIALS AND METHODS}

\section{Experimental unit configuration}

The experimental units were a pilot scale. Three types of tanks, with 1800-liter effective volume, were used as an experimental group. The design of the bottom of each tank varied geometrically, i.e., prism, pyramid, and rectangular. On the top of every tank were three similar trenches that had a 2-meter long biofilter bed. Every trench had three different water flow rates, i.e., $3 \mathrm{lpm}, 5 \mathrm{lpm}$ and $7 \mathrm{lpm}$. A 32 watt submersible pump was used to supply water from each fish tank to the three trenches, connected parallelly with $3 / 4$ inch PVC pipe. The water flow rate, as the treatment was adjusted, was done by the outflow head. Synchronization was carried out daily.

The fish species cultivated were tilapia (Oreochromis niloticus), sized $8.3 \pm 1.2 \mathrm{~g}$ and had 100 fishes per tank. In every trench, $50 \mathrm{~g}$ Azolla microphylla was added. The fish were fed ad satiation with floating pellets (CP. Prima 781$3,31-33 \%$ raw protein).

\section{Nutrient budgeting}

In the recirculating system, the complete water from the fish tank passed over the biofilter bed (the trench) once every 2 hours, then the water was mixed continuously in the fish tank, so that there were no differences between in and outflow. Samples were taken in fish tank only. Total Ammonia Nitrogen (TAN) as nutrient input and removal rates were calculated through mass balance. To estimate TAN input per day from within the fish tanks the following can be calculated based upon the feeding rate (Timmons et al. 2002):

$$
P_{\mathrm{TAN}}=F * \mathrm{PC} * 0,092
$$

Where:

$P_{\mathrm{TAN}}:$ Production rate of total ammonia nitrogen, (kg/day)

F : Feed rate (kg/day)

PC : Protein concentration in feed (decimal value)

The constant in the ammonia generation equation assumes that protein is $16 \%$ nitrogen, $80 \%$ nitrogen is assimilated by the organism, $80 \%$ assimilated nitrogen is excreted, and $90 \%$ of nitrogen is excreted as TAN+10\% as urea. In addition, the nitrogen in feces is not removed from the system but collected in the filter bed until the end of the experiment.

\section{Water quality}

Water quality parameters were monitored every three days such as temperature, $\mathrm{pH}$, dissolved oxygen (DO), Total Ammonia Nitrogen (TAN), and Un-ionized Ammonia Nitrogen $\left(\mathrm{NH}_{3}-\mathrm{N}\right)$. Lutron portable DO meter model 5510 was used to measure DO. The concentration of TAN was determined using TAONSUN spectrophotometer (Suzhou Taonsun Scientific Instruments, China).

\section{Biomass calculation}

Biomass growth of Azolla cultivated in biofilter units (gutter/trench) is expressed as doubling time (day ${ }^{-1}$ ) which is calculated according to daily growth rate (DGR, $\% / g /$ day) (Zonnenveld, et al., 1991) as follows:

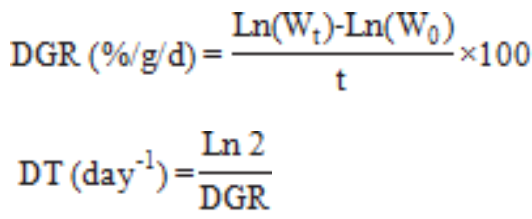

Where:

DGR: daily growth rate (\%/g/day)

Ln : logarithmic natural

$\mathrm{W}_{\mathrm{t}} \quad$ : final biomass of Azolla $(\mathrm{g})$

$\mathrm{W}_{0}$ : initial biomass of Azolla $(\mathrm{g})$

DT : Doubling Time

Total Ammonia Nitrogen measured on the final day of the experiment will represent the nutrient output. Thus, in case of this simple RAS, whereas all the water is recirculated and there is no discharge, nutrient removal rate can be calculated with mass balance equation (Al Hafedh et al., 2003) as follows:

Waste Loading Rate $\left(\mathrm{g} / \mathrm{m}^{3}\right.$ per day $)=C \mathrm{i} \times Q$

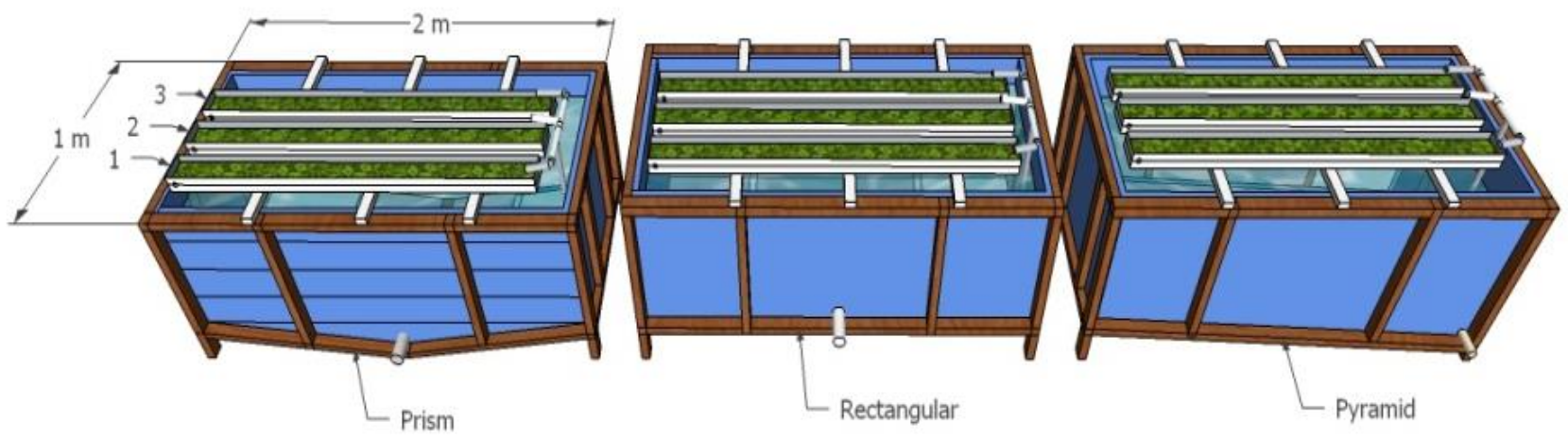

Figure 1. Sketch of experimental units configuration 
Waste Removal Rate $\left(\mathrm{g} / \mathrm{m}^{3}\right.$ per day $)=(C \mathrm{i}-C \mathrm{e}) \times Q$

Removal efficiency $(E)=\frac{\text { waste removal rate }}{\text { Waste loadingrate }} \times 100$

Where:

$\mathrm{Ci}$ : Total Ammonia Nitrogen measured in the fish $\operatorname{tank}(\mathrm{mg} / \mathrm{L} \mathrm{x}$ Water Volume $\mathrm{x} 1000=\mathrm{g})$

Ce $: P_{\text {TAN }}$ (Production rate of total ammonia nitrogen $(\mathrm{g})$

$\mathrm{Q}$ : Water flow (liter per minute, $\mathrm{lpm}$ )

Retained nitrogen of Azolla is expressed as gram and can be calculated by using the following formulae:

Retained Nitrogen $(\mathrm{RN}$, gram $)=\left(\mathrm{TKN}_{\mathrm{t}} \mathrm{x} \mathrm{W}_{\mathrm{t}}\right)-\left(\mathrm{TKN}_{0} \mathrm{x} \mathrm{W}_{0}\right)$

Retained Nitrogen Efficiency $(\mathrm{RNE}, \%)=\frac{\mathrm{RMS}}{\mathrm{P}_{\mathrm{LNS}}}$

Where:

$\mathrm{TKN}_{\mathrm{t}}$ : Total Kjedahl Nitrogen at the end of experiment $(\mathrm{g})$

$\mathrm{TKN}_{\mathrm{o}}$ : Initial Total Kjedahl Nitrogen $(\mathrm{g})$

$\mathrm{W}_{\mathrm{t}} \quad$ : Final biomass of Azolla $(\mathrm{g})$

$\mathrm{W}_{0} \quad$ : Initial biomass of Azolla $(\mathrm{g})$

\section{Data analysis}

The means on the Azolla growth rate, doubling time, and nitrogen retention parameters were analyzed using two-way analysis of variance (ANOVA, $\alpha=0.1$ ). The analysis was done using STATISTICA 8.0.

\section{RESULTS AND DISCUSSION}

\section{Nutrient input and biomass production of Azolla}

Total feed consumed by the fish in tanks I, II, and III were $1519 \mathrm{~g}, 1504 \mathrm{~g}$, and $1313 \mathrm{~g}$, respectively. The TAN production of every tank is listed in Table 1.

Based on the calculations, TAN production of all the fish tanks were evenly $3 \%$ of the total feed input. For example, tank I released $1.49 \mathrm{~g}$ TAN per day in 1800 liter of water. It means that $0.83 \mathrm{mg} . \mathrm{L}^{-1}$ of TAN was added and diluted in the water of the fish tank.

The TAN production was similar to the assumption of Colt (1991) that waste output of fish consuming $1000 \mathrm{~g}$ feed and $250 \mathrm{~g} \mathrm{O}_{2}$ are $30 \mathrm{~g}$ of TAN and $340 \mathrm{~g} \mathrm{CO}_{2}$ excreted via gill by ion-exchange along with $500 \mathrm{~g}$ fecal solid and $5.5 \mathrm{~g} \mathrm{PO}_{4}$-P. Then, Schneider et al. (2005) stated that the Fish-Biomass-Converter retains $20-50 \%$ feed $\mathrm{N}$ and $15-$ $65 \%$ feed $\mathrm{P}$. This means that $50-80 \%$ feed $\mathrm{N}$ and $35-85 \%$ feed $\mathrm{P}$ are discharged as waste.

Fish waste that was released in the water column was then recirculated and served as nutrient input for Azolla. The treatment with water flows showed no significant difference $(\mathrm{P}<0.1)$ among $3 \mathrm{lpm}, 5 \mathrm{lpm}$, and $7 \mathrm{lpm}$ on doubling time of Azolla's biomass (Figure 2).
Table 1. Feed consumption and TAN Production (PTAN) in 30 days

\begin{tabular}{lccc}
\hline Tank & $\begin{array}{c}\text { Feed consumed } \\
(\mathbf{g})\end{array}$ & $\begin{array}{c}\mathbf{P}_{\text {TAN }} \text { total } \\
(\mathbf{g})\end{array}$ & P $_{\text {TAN }}(\mathbf{g} /$ day $)$ \\
\hline I & 1519 & 44.7 & 1.49 \\
II & 1504 & 44.3 & 1.48 \\
III & 1313 & 38.6 & 1.29 \\
\hline
\end{tabular}

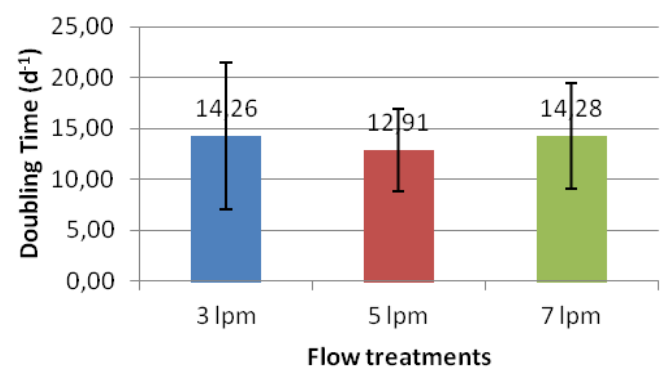

Figure 2. Doubling time of Azolla affected by water flow

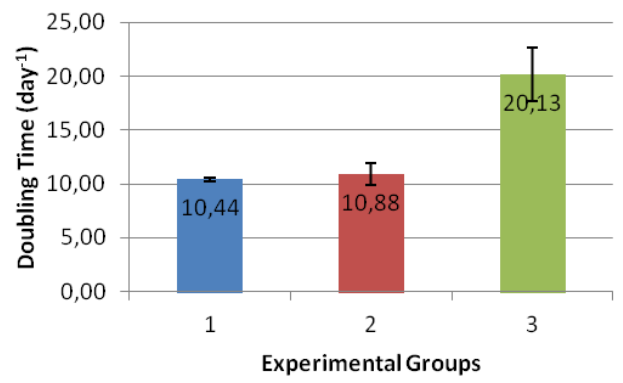

Figure 3. Doubling time of Azolla biomass affected by grouped-tank

Statistically, the significant difference in Azolla's biomass production occurred on experimental group-tank factors. Differences in the growth rate of the Azolla biomass in each experimental group related to the baseboard designs. This allowed better nutrient supply in Tank I and Tank II compared to Tank III. In Tanks I and II, the average biomass growth was doubled from the initial population that occurred every 10.44 and 10.88 days while in Tank III was every 20.13 days (Figure 3 ).

The result is inversely proportional to the TAN reduction pattern, which means that during the $1^{\text {st }}$ day until the $20^{\text {th }}$ day there was active ammonia assimilation by Azolla, and at the peak multiplication of the biomass the assimilation rate of $\mathrm{N}$ decreases, resulting in the TAN concentration in the water to rise again.

Azolla has been known to have the ability to fix nitrogen from the air, so that it can survive and keep growing under low nutrient conditions in the water. However, from the results of this study, there is a correlation between minimal TAN concentration and the rate of assimilation of $\mathrm{N}$ by Azolla. The TAN concentration in water should remain at a value of $>0.1 \mathrm{mg} . \mathrm{L}^{-1}$ to maintain the rate of assimilation of $\mathrm{N}$. If the TAN concentration $<0.1 \mathrm{mg} . \mathrm{L}^{-1}$ the assimilation of $\mathrm{N}$ tends to be slower or even stopped so that in this phase will result in cessation or decrease in growth rates of Azolla. 
Based on the results of Azolla Total Kjeldahl Nitrogen (TKN) analysis on the $30^{\text {th }}$ day showed that the average Azolla protein content in each treatment was different but not significant $(\mathrm{P}>0.10)$. The level of protein content present in Azolla in this study was relatively good (28.8\%) compared to the results of the tests with the duckweed (Lemna minor) in the same experimental design which reached $25.7 \%$ (Sumoharjo 2015). Therefore, it could be an alternative feed for herbivorous fish such as tilapia. The high levels of this protein content are influenced by Azolla's ability to convert nutrients from the water into Azolla biomass. The nitrogen retention by Azolla showed considerable value in each trial and showed significant differences between treatments as well as groups (Table 2).

The highest nitrogen retention was achieved by the 3 $\mathrm{lpm}$ treatment of $11.27 \pm 6.95 \mathrm{gN}$, followed by the $5 \mathrm{lpm}$ treatment of $9.23 \pm 7.28 \mathrm{gN}$, and the lowest was the $7 \mathrm{lpm}$ treatment which only retained $\mathrm{N}$ of $7.97 \pm 6.22 \mathrm{~g}$.

\section{TAN removal efficiency}

The TAN conversion rates were determined as overall retained nitrogen of Azolla from $\mathrm{P}_{\mathrm{TAN}}$ of every tank as part of the experimental group (Figure 4). The results of this experiment showed that the efficiency of the TAN removal by Azolla was still lower than the treatment using Lemna minor which reached $48 \%$ but was much higher than Spyrogyra sp which retained $2.91 \% \mathrm{~N}$ of TAN produced by tilapia (Sumoharjo 2015). Determining how much TAN removal will greatly determine the potential level of the use of a phototrophic organism as a biofilter for the use of water quality management in RAS.

\section{Water quality and nitrogen dynamics}

Water quality characteristics, such temperature ranged between 27.3 to $30.7^{\circ} \mathrm{C}$, while $\mathrm{pH}$ and TAN tended to decrease during experiment (Figure 5). The proportion of $\mathrm{NH}_{3}$ increased with higher $\mathrm{pH}$. It could be because TAN

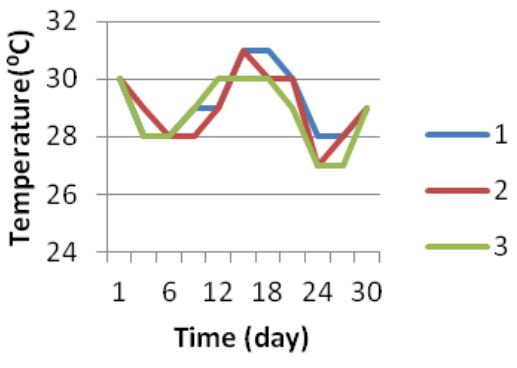

A

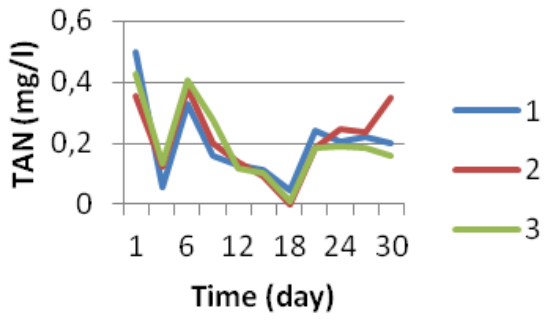

C enters the organism as $\mathrm{NH}_{3}$ (Randall and Tsui 2002). Therefore, the toxicity of TAN (the total $\mathrm{NH}_{3}-\mathrm{N}$ and $\mathrm{NH}_{4}{ }^{+}-$ $\mathrm{N}$ ) increased in line with the increase of $\mathrm{pH}$ of the water. Fortunately, $\mathrm{pH}$ during the experiment tended to decline from $7.9 \pm 0.2$ at the beginning to $6.6 \pm 0.2$ at the end of experiment. So that the proportion of un-ionized ammonia $\left(\mathrm{NH}_{3}\right)$ was low and in a tolerable concentration for Tilapia. The toxic level of $\mathrm{NH}_{3}$ for short-term exposure usually are reported in between 0.6 to $2 \mathrm{mg} . \mathrm{L}^{-1}$, while the maximum tolerable concentration is to be $0.1 \mathrm{mg} . \mathrm{L}^{-1}$ (Pillay 1992). Moreover, the specific growth rate (SGR) of tilapia exposed to un-ionized ammonia nitrogen over $0.068 \mathrm{mg}$ $\mathrm{NH}_{3}$ was significantly reduced. The specific growth rate and the increase of the unionized ammonia concentration increased the feed conversion ratio (El-Syafai 2004).

Table 2. Variance analysis of retained nitrogen by Azolla

\begin{tabular}{lcrrrr}
\hline Source & \multirow{2}{*}{ Degr. of } & $\begin{array}{c}\text { RN } \\
\text { SS }\end{array}$ & \multicolumn{1}{c}{ RN } & \multicolumn{1}{c}{ RN } & \multicolumn{1}{c}{ RN } \\
Treatments & 2 & 16.4019 & 8.2009 & 8.7203 & $0.034805^{*}$ \\
Groups & 2 & 276.2516 & 138.1258 & 146.8737 & $0.000180^{*}$ \\
Error & 4 & 3.7618 & 0.9404 & & \\
Total & 8 & 296.4152 & & & \\
\hline
\end{tabular}

Note: *: Significant difference on $90 \%$ of reliability

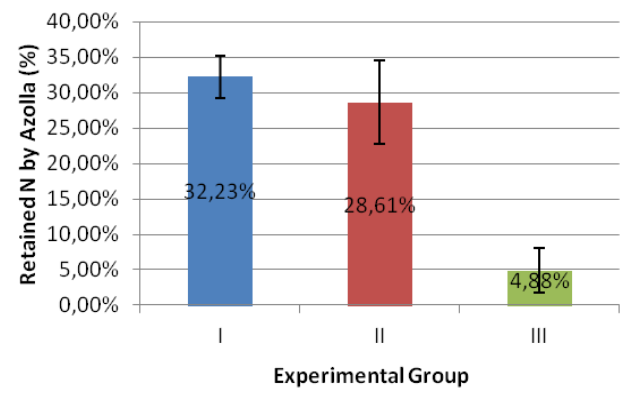

Figure 4. TAN Removal efficiency
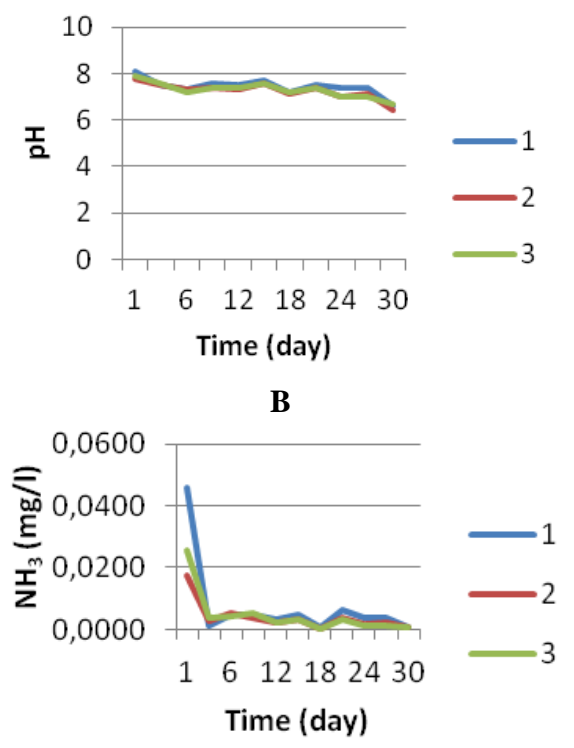

D

Figure 5. Water quality characteristics: A. Temperature, B. pH, C. TAN, D. The proportion of $\mathrm{NH}_{3}$ 
Table 3. Means and standard deviations of water quality characteristics

\begin{tabular}{lcccc}
\hline \multicolumn{1}{c}{$\begin{array}{c}\text { Water } \\
\text { quality } \\
\text { parameters }\end{array}$} & Unit & \multicolumn{3}{c}{ Tank } \\
\cline { 3 - 5 } & & I & II & III \\
Temperature & ${ }^{\circ} \mathrm{C}$ & $29.2 \pm 1.2$ & $29.0 \pm 29.0$ & $28.8 \pm 1.2$ \\
pH & & $7.4 \pm 0.4$ & $7.3 \pm 0.4$ & $7.3 \pm 0.3$ \\
DO & mg.L & $4.1 \pm 1.4$ & $3.6 \pm 1.2$ & $4.0 \pm 1.7$ \\
CO2 & mg.L & $21.0 \pm 11.4$ & $23.2 \pm 13.3$ & $22.0 \pm 11.7$ \\
TAN & mg.L & $0.20 \pm 0.1$ & $0.21 \pm 0.1$ & $0.20 \pm 0.1$ \\
NH3 & mg.L & $0.007 \pm 0.013$ & $0.004 \pm 0.005$ & $0.005 \pm 0.007$
\end{tabular}

Carbon dioxide $\left(\mathrm{CO}_{2}\right)$ is another factor that may affect feed behavior (Trand-Duy et al. 2008). In an intensive culture system, $\mathrm{CO}_{2}$ may not have an adverse effect on fish unless its concentration reaches $100 \mathrm{mg} . \mathrm{L}^{-1}$ (Balarin and Heller 1982). Nile tilapia can tolerate $\mathrm{CO}_{2}$ concentration above $20 \mathrm{mg} . \mathrm{L}^{-1}$ (Wedemeyer 1996). In this study, $\mathrm{CO}_{2}$ was $30.2 \pm 3 \mathrm{mg} . \mathrm{L}^{-1}$ on the first day then decrease to $15.2 \pm 1.1$ on the $30^{\text {th }}$ day of the experiment (Table 3 ). $\mathrm{CO}_{2}$ tended to decrease during the experiment because the turbulences that occurred in inflow and outflow of the Azolla reactor may strip $\mathrm{CO}_{2}$ to atmosphere. Moreover, algae and Azolla thrived in the reactors play a role in removing $\mathrm{CO}_{2}$ out of the system.

Concentration of dissolved oxygen (DO) during the experiment ranged between 2,2 to $6,2 \mathrm{mg}^{-\mathrm{L}^{-1}}$ (Table 3 ). The lowest DO concentration occurred on the last day of the experiment. Accumulation of sludge in the Azolla reactor played a role in decreasing DO gradually. This may happen because there is no sludge disposal from the system. DO should be maintained above $3.0 \mathrm{ppm}$ and $5.0 \mathrm{ppm}$ for warm and cold-water fish, respectively (Buttner et al. 1993). However, most species of fish are distressed when DO falls to 2-4 mg.L - $^{-1}$ (Floyd 2003).

The lower extreme value of DO (less than $0.8 \mathrm{mg} . \mathrm{L}^{-1}$ ) was obtained from an experiment in which there were no significant differences between the yields of Nile tilapia raised in ponds with two aeration regimes (TeichertCoddington and Green 1993). Thus, practical threshold of DO for Nile tilapia was not higher than $10 \%$ of saturation (0.8 mg.L $\mathrm{L}^{-1}$ at $\left.26^{\circ} \mathrm{C}\right)$ (Trand-Duy et al. 2008).

In conclusion, Azolla microphylla can be grown well in RAS. The assimilation rate of TAN by Azolla decreased after its peak biomass production (when doubling time was achieved). Therefore, harvesting must be done 15 to 18 days after cultivation. As a biofilter, it provides a miniecosystem that serves as nutrient controller for aquaculture practices. The lower water flow rate the higher nitrogen retention, although, there was no significant effect of water flow rates on the Azolla growth response. It has enough protein content, hence has potential as feed source for herbivorous fishes.

\section{ACKNOWLEDGEMENTS}

The authors would like to thank the Faculty of Fisheries and Marine Science, Mulawarman University, Samarinda, Indonesia for the financial support through operational funding for research and development, Mulawarman University, the year 2017.

\section{REFERENCES}

Al Hafedh YS, Alam A, Alam MA. 2003. Performance of plastic biofilter media with different configurations in a water recirculation system for the culture of Nile tilapia (Oreochromis niloticus). J Aquacult Eng 29: 139-154.

Balarin JD, Haller RD. 1982. The intensive culture of tilapia in tanks, raceways and cages. In: Muir JF, Roberts RJ. (eds.), Recent Advances in Aquaculture. Westview Press Inc., Colorado.

Bradfield AE. 1985. Laboratory studies of energy budgets. In: Tytler P, Calow P. (eds.), Fish Energetics: New Perspectives. John Hopkins University Press, Baltimore.

Brune DE, Schwartz G, Eversole AG, Collier JA, Schwedler TE. 2003. Intensification of pond aquaculture and high rate photosynthetic systems. Aquacult Eng 28: 65-86.

Buttner JK, Soderberg RW, Terlizzi DE. 1993. An Introduction to Water Chemistry in Freshwater Aquaculture. Massachusetts: NRAC Fact Sheet No. 170.

Colt J.1991. Aquaculture production system. J Anim Sci 69: 4183-4192.

Datta SN. 2002. Culture of Azolla and its efficacy in diet of Labeo rohita. Aquaculture 310: 376-379.

El-Syafai SA, El-Gohary FA, Nasr FA, Van Der Steen FE, Gijzen HJ. 2004. Chronic ammonia toxicity to duckweed-fed tilapia (Oreochromis niloticus). Aquaculture 232: 117-127.

FAO (Food and Agriculture Organization of the United Nations). 2009. Use of algae and aquatic macrophytes as feed in small-scale aquaculture: A Review. FAO-Fisheries and Aquaculture Technical Paper, 531. Food and Agriculture Organization of the United Nations. Rome, Italy.

Fiogbé EDJC, Micha C, Van Howe. 2014. Use of a natural aquatic fern, Azolla microphylla, as a main component in food for the omnivorous -phytoplanktonophagous tilapia, Oreochromis niloticus L. J Appl Ichthyol 20: 517-520.

Floyd RF. 2003. Oxygen for fish production. FACT Sheet FA-27. Extention-Institute of Food and Agricultural Science. University of Florida, Gainesville, FL.

Handy RD, and Poxton MG. 1993. Nitrogen pollution in mariculture: toxicity and excretion of nitrogenous compounds by marine fish. Rev Fish Biol Fish 3 (3): 205-241.

Liu TL, Sun PB. 2008. Effect Ammonium on Blood Characteristic and Lypooxigenase Activities in Cultured Tilapia. Department of Food Science. National Taiwan Ocean University, Taiwan.

Lumpkin TA, Plucknett DL. 1980. Azolla: Botany, physiology and use as a green manure. Econ Bot 34: 111-134.

Nerici C, Silva A, Merino G. 2012. Effect of two temperatures on ammonia excretion rates of Seriolella violacea (Palm fish) juveniles under rearing conditions. Aquacult Eng 46: 47-52.

Pillay TVR. 1992. Aquaculture and the Environment. 1st ed. Cambridge University Press, Cambridge.

Rafee G, Saad CR. 2005. Nutrient cycle and sludge production during different stages of red tilapia (Oreochromis sp.) growth in a recirculating aquaculture system. Aquaculture 244: 109-118.

Randall D, Tsui T. 2002. Ammonia toxicity in fish. Mar Poll Bull 45: 1723.

Schneider O, Sereti V, Eding EH, Verreth JAJ. 2005. Analysis of nutrient flows in integrated intensive aquaculture systems. J Aquacult Eng 32: 379-401.

Smith M. 2003. Biological Filters for Aquaculture. L.S. Enterprises, Fort Fort Myers, FL, USA.

Sumoharjo. 2015. Performance of duckweed (Lemna minor) as biofilter in recirculating aquaculture system. J Trop Fish Sci 21: 86-94. 
Teichert-Coddington D, Green BW. 1993. Tilapia yield improvement through maintenance of minimal oxygen concentrations in experimental grow-out ponds in Honduras. Aquaculture 118: 63-71.

Timmons MB, Ebeling JM, Wheaton FW, Summerfelt ST, Vinci BJ. 2002. Recirculating Aquaculture Systems, 2nd ed. Cayuga Aqua Ventures, New York.

Tran-Duy A, Schrama JW, Van Dam AA, Vereth JAJ. 2008. Effects of oxygen concentration and body weight on maximum feed intake, growth and hematological parameters of Nile tilapia, Oreochromis niloticus. Aquaculture 275: 152-162.

Van Hove C. 1989. Azolla and its Multipurpose Uses with Emphasis on Africa. FAO, Rome.

Wedemeyer GA. 1996. Physiology of fish in intensive culture. Chapman and Hall, New York.

Zonnenveld A, Huisman EA, Boon JH. 1991. The Principles of Aquaculture. PT. Gramedia Pustaka Utama, Jakarta. [Indonesian] 